\title{
Diallel analysis for bodyweight involving three genotypes of Nigerian indigenous chickens
}

\author{
A.A. Musa ${ }^{1 \#}$, M. Orunmuyi ${ }^{2}$, G.N. Akpa ${ }^{3}$, A.K. Olutunmogun ${ }^{4}$, H. Muhammad $^{3}$ \& I.I. Adedibu ${ }^{3}$ \\ ${ }^{1}$ Department of Animal Production, Kogi State University, Anyigba, Kogi State, Nigeria \\ ${ }^{2}$ Department of Animal Production and Health, Federal University, Oye-Ekiti, Ekiti State, Nigeria \\ ${ }^{3}$ Department of Animal Science, Ahmadu Bello University, Zaria, Kaduna State, Nigeria \\ ${ }^{4}$ National Animal Production Research Institute, Shika, Zaria, Kaduna State, Nigeria
}

(Received 11 August 2014; Accepted 13 April 2015; First published online 10 July 2015)

Copyright resides with the authors in terms of the Creative Commons Attribution 2.5 South African Licence.
See: http://creativecommons.org/licenses/by/2.5/za
Condition of use: The user may copy, distribute, transmit and adapt the work, but must recognise the authors and the South African
Journal of Animal Science.

\begin{abstract}
To evaluate heterosis, reciprocal effect, general and specific combining abilities for bodyweight, a diallel crossing experiment was conducted using three genotypes of Nigerian indigenous chickens: normal $(\mathrm{N})$, frizzle $(\mathrm{F})$ and naked-neck $(\mathrm{Na})$. A total of 601 chicks was hatched from all possible matings between the three genotypes. The chicks used in this study were hatched from a foundation stock of 90 chickens comprising 25 hens and 5 cocks for each of the three genotypes. A mating ratio of 1 male : 5 females was employed. Furthermore, data on bodyweight were scrutinized with complete diallel analysis after they had been corrected for significant effects of hatch of birds using least squares constants. The results revealed that bodyweight (BWT) was significantly influenced by genetic groups with the frizzle-naked (FNa) having the best performance at all ages (4 - 20 weeks) except at hatch, with a mean final BWT of $1173 \mathrm{~g}$ at 20 weeks old. The next best performing was its reciprocal, the naked-frizzle (NaF), with a mean final BWT of $1162 \mathrm{~g}$. Furthermore, the FNa gave the best estimates for heterosis and specific combining ability, while the $\mathrm{F}$ and $\mathrm{NNa}$ gave the best estimates for general combining ability and reciprocal effect, respectively. Therefore, the F genotype as sire and the $\mathrm{Na}$ as dam provided the most suitable combination for improved BWT. Furthermore, the use of the Na genotype as dam was more suitable owing to the significant reciprocal effect.
\end{abstract}

Keywords: Combining abilities, frizzle-feathered, heterosis, naked-neck, normal-feathered

\# Corresponding author: mailraheem2003@yahoo.com

\section{Introduction}

The poultry population in Nigeria is estimated to be 172 million, of which chickens are approximately 160 million, guinea fowl 8.3 million, ducks 1.7 million and local turkeys 1.05 million (FAOSTAT, 2011). Nigerian indigenous chickens have been described as small-bodied, slow growing, poor feed converters and poor meat animals (Ajayi, 2010). Despite these shortcomings, they are valued for their heat tolerance, meat quality, general hardiness and ability to scavenge (Petrus, 2011). However, selection in indigenous breeds has been targeted more at adaptation to tropical harsh environments and resistance to diseases than to enhanced production (Minga et al., 2004). An improvement in growth traits such as bodyweight (BWT) becomes imperative.

Genetic progress can be attained by selection and crossbreeding (Adebambo et al., 2011). Crossbreeding could lead to the production of birds that would be better in growth rate and efficiency of feed conversion without sacrificing adaptation to the indigenous environment, thereby resulting in reduced cost of production (Adebambo et al., 2011). The outcome of crossbreeding is owing to the phenomenon of heterosis, which is expressed in the performance of hybrids. Since heterosis is almost exclusively the aggregate of all single-locus dominance effects, and as these are usually beneficial, heterosis can be expected to be in a favourable direction (Kitalyi, 1999).

The test for good combining abilities is developed by generating a diallel cross, which is a set of possible combinations between several genotypes and general populations and the analysis of data from such crosses (Hayman, 1954). The general combining ability (GCA) is defined as the average performance of a line (strain, breed or genotype) in hybrid combination with other lines (Gardner \& Eberhardt, 1966). The variation in GCA is owing to additive genetic variance. Specific combining ability (SCA) refers to a cross produced by a pair of lines (Adebambo et al., 2010). It indicates cases in which certain combinations 
(crosses) do relatively better or worse than would be expected, based on the average performance, that is, GCA of the two lines involved in producing that combination. The variation in SCA is owing to non-additive genetic variance, heterosis, dominance, over-dominance and epistasis (Singh \& Kumar, 1994).

Large variations have been reported among the birds in morphological, immune response, growth and reproductive traits (Peters, 2000; Msoffe et al., 2001). This has led to the conclusion that indigenous chickens are repositories of unique genes that could be used in other parts of the world (Adebambo, 2005), hence the need for their conservation to keep genetic variation in and between indigenous breeds. A series of reports on the characterization of indigenous chickens revealed that they could be classified based on the occurrence of some major genes, such as the dwarf gene, naked-neck gene and frizzling gene (Ikeobi et al., 1996). Naked-neck and frizzle birds have been found to be thermally stress tolerant compared with their normally feathered counterparts (Nwachukwu et al., 2006). The naked-neck and frizzle genes have been found to be associated with heat tolerance, and therefore in areas with high ambient temperature, birds with these genes are superior to their normally feathered counterparts for feed efficiency (Garces et al., 2001). According to Fayeye et al. (2006), birds with the naked-neck and frizzle genes have better adult bodyweights than their normally feathered counterparts. Furthermore, many investigators have confirmed the superiority of crossbreds over purebreds regarding growth traits in chicken (Khalil et al., 2004; Nwachukwu et al., 2006).

There is a dearth of information on diallel analysis for BWT involving normal-feathered, frizzlefeathered and naked-neck Nigerian indigenous chickens. This study was therefore designed to investigate the heterosis, GCA, SCA and reciprocal effects for bodyweight of three genotypes of Nigerian indigenous chicken in a diallel crossing experiment.

\section{Materials and Methods}

The study was conducted at the Experimental and Research Farm of the Department of Animal Science, Faculty of Agriculture, Ahmadu Bello University, Zaria, Nigeria. The area is situated between latitudes $110 \mathrm{~N}$ and $120 \mathrm{~N}$ and an altitude of $640 \mathrm{~m}$ (Akpa et al., 2013).

A total of 90 sexually matured indigenous chickens, comprising 25 hens and five cocks, each of the three genotypes (normal-feathered, frizzle-feathered and naked-neck) was used as the foundation stock for this study. This foundation stock was randomly purchased from Katsina (Funtua), Kaduna (Shika, Giwa) and Kogi (Anyigba, Okene) States. The birds were fed breeder mash (10.54 MJ ME/kg and $180 \mathrm{~g}$ crude protein $/ \mathrm{kg}$ ), and water was offered ad libitum. They were raised on deep litter and pen mating was carried out using a mating ratio of 1 male : 5 females.

Fertile eggs were collected, stored for a maximum of seven days, sorted out sire-wise, marked according to sire identification numbers and within genotypes. The eggs were fumigated with potassium permanganate and hydrogen peroxide in the fumigation room for about 30 minutes and later taken to the incubator at a temperature of about $37^{\circ} \mathrm{C}$. Candling the eggs was done on the 18th day of incubation, and fertile eggs were transferred to the hatcher. Hatching trays were partitioned into compartments according to sire numbers and genotypes. Eggs belonging to the same sire were put in the same compartment. Hatching was completed on the 21st day of incubation and resulted in the F1 generation.

A total of 601 chicks was hatched from all possible matings among the three genotypes. The possible matings are explained in Table1. The chicks were wing-tagged and pedigreed according to sire identification number, and brooded with the aid of electric bulbs. They were fed chick mash (11.9 MJ ME/kg and 210 crude protein $/ \mathrm{kg}$ ) from 0 to 8 weeks old and grower mash $(10.04 \mathrm{MJ} \mathrm{ME} / \mathrm{kg}$ and $160 \mathrm{~g}$ crude protein $/ \mathrm{kg}$ ) from eight weeks old until the end of the study ( 20 weeks old). They were also vaccinated against common poultry diseases such as Newcastle, infectious bursal (Gumboro) and fowl-pox. Other routine medication and management operations included anti-coccidial medication, de-worming and delousing.

Bodyweight $(\mathrm{g})$ was measured with a sensitive $(1 \mathrm{~g})$ top-loading scale (Citizen Electronic Balance, Goldair $^{\circledR}$ ). Bodyweight was recorded at day old and at four-week intervals until 20 weeks old. The general linear model procedure of Statistical Analysis System program (SAS, 2002) was used to test the effects of the genetic groups and sex. Significant means were separated using Tukey's studentized range (HSD) test. The following model was used to analyse the BWT trait:

$Y_{i j k}=\mu+G_{i}+S_{j}+e_{i j k}$

where: $\quad Y_{i j k}=$ bodyweight of bird of the jth sex in the ith genetic group

$\mu=$ overall mean

$\mathrm{Gi}=$ effect of the ith genetic group 


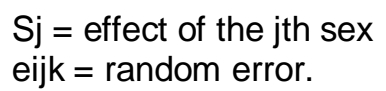

Table 1 Mating scheme of foundation stock for the production of F1 generation

\begin{tabular}{llll}
\hline Male & & Female & Progeny \\
\hline Pure cross & & & \\
Normal feathered & $\times$ & Normal feathered & $\mathrm{N}$ \\
Frizzle feathered & $\times$ & Frizzle feathered & $\mathrm{F}$ \\
Naked-neck & $\times$ & Naked-neck & $\mathrm{Na}$ \\
Main cross & & & $\mathrm{NF}$ \\
Normal feathered & $\times$ & Frizzle feathered & $\mathrm{FNa}$ \\
Frizzle feathered & $\times$ & Naked-neck & $\mathrm{NaN}$ \\
Naked-neck & $\times$ & Normal feathered & \\
Reciprocal cross & & & $\mathrm{FN}$ \\
Frizzle feathered & $\times$ & Normal feathered & $\mathrm{NaF}$ \\
Naked-neck & $\times$ & Frizzle feathered & $\mathrm{NNa}$ \\
Normal feathered & $\times$ & Naked-neck & \\
\hline
\end{tabular}

Heterosis was calculated according to Fairfull (1990) by applying the following formula:

$\mathrm{H} \%=\mathrm{AB}-(0.5 \mathrm{AA}+0.5 \mathrm{BB}) /(0.5 \mathrm{AA}+0.5 \mathrm{BB}) \times 100$.

Where: $\quad H \%=$ percent heterosis

$\mathrm{AB}=$ crossbred

$A A$ and $B B=$ sire and dam genotypes, respectively.

The diallele 1 procedure of plant breeding package of $R$ Core Team (2013) was used to estimate the general combining ability (GCA), specific combining ability (SCA) and reciprocal effects (RE) according to Griffing's (1956) method I, using a random model (Model II). The following model was used:

$Y_{i j k}=\mu+g_{i}+g_{j}+s_{i j}+r_{i j}+e_{i j k}$

where: $\quad Y_{\mathrm{ijk}}=$ observed value of each experimental unit

$\mu=$ population mean

$\mathrm{g}_{\mathrm{i}}=\mathrm{GCA}$ effect for $\mathrm{i}^{\text {th }}$ genotype

$g_{j}=$ GCA effect for $j^{\text {th }}$ genotype

$s_{i j}=$ SCA effect for the cross $(i, j)$

$r_{i j}=R E$ effect of the cross $(i, j)$

$\mathrm{e}_{\mathrm{ijk}}=$ random observation error among replicates.

Note: Preliminary analysis was carried out to test for effect of hatch. Where it was found to have a significant effect, the data were transformed by adding or subtracting least square constants according to Harvey's (1966) method.

\section{Results}

Table 2 shows the least square means and coefficient of variation for BWT of indigenous chickens by age across genetic groups. At day old, frizzled (F) recorded the BWT of $25.8 \mathrm{~g}$, which was higher $(P<0.01)$ than that of normal-naked $(\mathrm{NNa})(22.6 \mathrm{~g})$. Bodyweight at 4 weeks old was lower $(P<0.01)$ in naked-normal $(\mathrm{NaN})$, naked-neck $(\mathrm{Na})$, normal $(\mathrm{N})$ and naked-frizzle (NF) than in the frizzle (F) and frizzled-naked (FNa) who recorded the BWTs. At 8 weeks old, F recorded BWT of $345.2 \mathrm{~g}$ which was higher $(P<0.05)$ than NaN $(305.6 \mathrm{~g})$ and $\mathrm{NNa}(310.6 \mathrm{~g})$ which recorded the lowest BWT. FNa recorded highest $(P<0.01)$ BWTs at 12 , 
16 and 20 weeks old while NaN was consistently the lowest. The coefficient of variation (\%) ranged from 14.92 (BWT0) to 22.01 (BWT4).

Heterotic estimates for BWT from day old to 20 weeks old are presented in Figure 1. Results revealed that heterosis was negative only from day old to 8 weeks old in NF and $\mathrm{NaF}$ while it was negative in $\mathrm{FN}$ up to 12 weeks old. Heterosis was positive at all ages in $\mathrm{FNa}$, except at day old, while it was negative at all ages in $\mathrm{NaN}$ except at day old. In NNa, heterosis was positive at all ages except at day old and 8 weeks old.

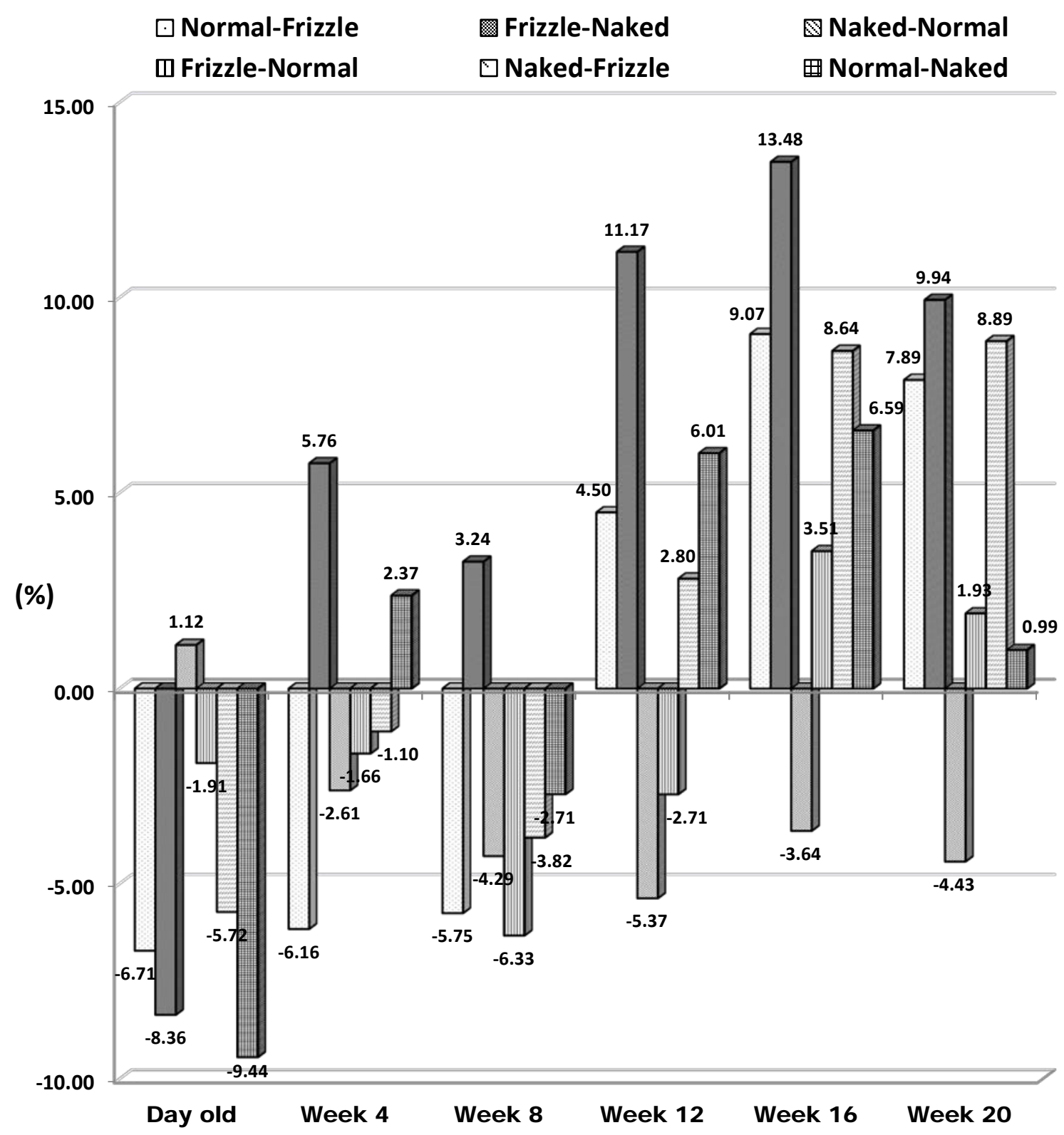

Figure 1 Heterotic estimates for bodyweight from day old to 20 weeks old.

The crossbreeding genetic estimates for GCA, SCA and RE for BWT at day old to 20 weeks old are presented in Table 3. The crossbreeding genetic estimates obtained for GCA were positive at 4 and 8 weeks old only. However, the values were significant $(P<0.05)$ only at 4 weeks old. Similarly, the crossbreeding 
Table 2 Least square means and coefficient of variation for bodyweight (g) from 0 to 20 weeks old across genetic groups of Nigerian indigenous chickens

\begin{tabular}{|c|c|c|c|c|c|c|c|}
\hline Traits & NO (601) & BWT0 & BWT4 & BWT8 & BWT12 & BWT16 & BWT20 \\
\hline \multicolumn{8}{|c|}{ Purebred } \\
\hline $\mathrm{N}$ & 101 & $25.5^{\mathrm{ab}} \pm 0.36$ & $101.5^{b} \pm 2.22$ & $324.8^{\mathrm{abc}} \pm 6.88$ & $584.5^{\mathrm{bc}} \pm 12.40$ & $723.6^{d} \pm 15.95$ & $1083.0^{\mathrm{abcd}} \pm 22.74$ \\
\hline$F$ & 55 & $25.8^{a} \pm 0.49$ & $111.5^{a} \pm 3.12$ & $345.2^{\mathrm{a}} \pm 9.95$ & $584.9^{\mathrm{bc}} \pm 17.94$ & $741.9^{\text {cd }} \pm 23.07$ & $1062.2^{\mathrm{cd}} \pm 32.88$ \\
\hline $\mathrm{Na}$ & 73 & $24.5^{b c} \pm 0.43$ & $100.6^{b} \pm 2.53$ & $313.7^{\mathrm{bc}} \pm 7.89$ & $577.9^{b c} \pm 12.23$ & $763.0^{\mathrm{bcd}} \pm 18.29$ & $1071.9^{\mathrm{bcd}} \pm 26.08$ \\
\hline \multicolumn{8}{|c|}{ Main crosses } \\
\hline NF & 38 & $23.9^{c} \pm 0.59$ & $103.1^{b} \pm 3.88$ & $315.7^{b c} \pm 11.66$ & $611.0^{\mathrm{ab}} \pm 21.04$ & $799.2^{\mathrm{abc}} \pm 27.06$ & $1157.3^{\mathrm{abc}} \pm 38.56$ \\
\hline $\mathrm{FNa}$ & 74 & $23.5^{\mathrm{cd}} \pm 0.43$ & $112.1^{a} \pm 2.72$ & $340.2^{\mathrm{ab}} \pm 8.39$ & $646.3^{a} \pm 15.13$ & $831.5^{a} \pm 19.45$ & $1173.2^{\mathrm{a}} \pm 27.73$ \\
\hline $\mathrm{NaN}$ & 82 & $25.3^{\mathrm{ab}} \pm 0.40$ & $98.4^{b} \pm 3.88$ & $305.6^{c} \pm 8.10$ & $550.0^{C} \pm 14.57$ & $716.2^{d} \pm 18.74$ & $1029.7^{d} \pm 26.71$ \\
\hline \multicolumn{8}{|c|}{ Reciprocal crosses } \\
\hline FN & 52 & $25.2^{\mathrm{ab}} \pm 0.51$ & $104.7^{\mathrm{ab}} \pm 3.34$ & $316.0^{\mathrm{bc}} \pm 9.73$ & $568.9^{\mathrm{C}} \pm 17.56$ & $758.4^{\mathrm{bcd}} \pm 22.58$ & $1093.3^{\mathrm{abcd}} \pm 32.18$ \\
\hline $\mathrm{NaF}$ & 72 & $23.7^{\mathrm{cd}} \pm 0.43$ & $104.9^{\mathrm{ab}} \pm 2.85$ & $316.9^{b c} \pm 8.59$ & $597.7^{\mathrm{abc}} \pm 15.50$ & $817.4^{\mathrm{ab}} \pm 19.93$ & $1161.9^{\mathrm{ab}} \pm 28.41$ \\
\hline $\mathrm{NNa}$ & 54 & $22.6^{d} \pm 0.50$ & $103.5^{\mathrm{ab}} \pm 3.28$ & $310.6^{C} \pm 10.07$ & $616.1^{\mathrm{ab}} \pm 18.16$ & $792.3^{\mathrm{abc}} \pm 23.35$ & $1089.1^{\mathrm{abcd}} \pm 33.28$ \\
\hline SEM & & 0.15 & 0.95 & 2.92 & 5.23 & 6.70 & 9.57 \\
\hline CV \% & & 14.92 & 22.01 & 20.62 & 20.10 & 19.83 & 19.77 \\
\hline LOS & & ** & ** & * & ** & ** & ** \\
\hline
\end{tabular}

abcd Means with different superscripts on the same column are significantly different; BWT0, BWT4, BWT8, BWT12, BWT16 and BWT20 mean bodyweights at 0, 4, 8, 12, 16 and 20 weeks, respectively.

F: frizzled; FN: frizzled-normal; FNa: frizzled-naked; N: normal; Na: naked-neck; NaF: naked-frizzled; NaN: naked-normal; NF: normal-frizzled; NNa: normal-naked.

SEM: standard error of means; CV: coefficient of variation; LOS: level of significance.

* $P<0.05$; ** $P<0.01$; NO: number of observations. 
genetic estimates for RE were negative at 8 weeks old only, but the values were significant $(P<0.05)$ at day old and 12 weeks old only. The crossbreeding genetic estimates for SCA for BWT were negative only at the 4 weeks old. However, the values were significant $(P<0.05)$ at 16 weeks old and $(P<0.01)$ at 20 weeks old.

Table 3 Crossbreeding genetic estimates for general, specific combining abilities and reciprocal effects for bodyweight at day old to 20 weeks old

\begin{tabular}{lcccccc}
\hline Parameters & Day old & Week 4 & Week 8 & Week 12 & Week 16 & Week 20 \\
\hline GCA & -0.03 & $8.88^{\star}$ & 36.4 & -169.4 & -23.5 & -703.5 \\
SCA & 0.36 & -4.48 & 26.2 & 477.1 & $873.1^{\star}$ & $4040.0^{\star \star}$ \\
RE & $0.48^{\star}$ & 0.21 & -5.9 & $456.5^{\star}$ & 299.9 & 232.6 \\
\hline
\end{tabular}

GCA: general combining ability; SCA: specific combining ability; RE: reciprocal effect.

* $P<0.05 ; * \star P<0.01$.

Figure 2 depicts the estimates of GCA, SCA and RE for BWT at various ages. GCA estimates for N were negative at all ages except for day old, while $\mathrm{F}$ was negative only at the 12th week. Na showed negative estimates from hatch to the 8th week, but were positive from the 12th week to the 20th week. SCA was negative for NF, except at the 12th week, positive for NaN only at the 12th and 16th week but positive through all periods and increased progressively from hatch to 20 weeks for FNa. RE estimates were positive from hatch to the 8th week only for FN, negative only at hatch for NNa, while for NaF positive only at day old, 4th and 20th week.

\section{Discussions}

The range of day-old BWT in this study was within that of $22.3 \mathrm{~g}$ to $30.9 \mathrm{~g}$ reported by Oke (2011) in three genotypes of Nigerian indigenous chickens and their crosses. It was also similar to the range of 21.8 to $28.1 \mathrm{~g}$ recorded by Ndofor-Foleng et al. (2010) for light and heavy ecotype chickens with their main crosses. The significantly higher day-old bodyweight in $\mathrm{F}$ suggests that the gene may have the potential for rapid growth. This is in accordance to the report of Oke (2011), who also reported ascendant day-old weight in F and FN.

The range for BWT4 in this study fell slightly below the $101.4-129.2 \mathrm{~g}$ recorded by Oke (2011) and was higher than the 86.3 - $91.9 \mathrm{~g}$ reported by Egahi et al. (2013). This can be attributed to the differences in experimental setup and environment. The findings in the present study, where there was significant variation in BWT4 among genetic groups, contradicted Mahrous (2008) and Oke (2011), who had previously reported that there are no differences between the main and reciprocal crosses for bodyweight at this age. The FNa and $\mathrm{F}$ genetic groups, which had the highest weights, were consistent with the report of Mahrous et al. (2008) that the duo of $\mathrm{F}$ and $\mathrm{Na}$ genes conferred fast-growing ability, either singly or in pairs. Correspondingly, F and FNa genetic groups retained far superior performance of BWT8, indicating excellent individual and combining patterns for these major genes. BWT12 to BWT20 showed that the FNa and its reciprocal NaF out-performed all other groups. These observations agree with the findings of Mahrous (2008) and Oke (2011). This ascendancy may be as a result of efficiency of thermoregulation imparted by the two genes (Yunus \& Cahaner, 1999).

Range of values obtained for these periods compared favourably with the findings of Egahi et al. (2013), who reported values of 500.5 - $639.5 \mathrm{~g}, 734.4$ - $842.3 \mathrm{~g}$, and 1017.6 - $1121.8 \mathrm{~g}$ for BWT12, BWT16 and BWT20, respectively. The coefficient of variation for BWT by period was highest at BWT4 indicating that BWT varied more at 4 weeks old among genetic groups. The superior performance of $\mathrm{F}$ and $\mathrm{Na}$ with their crosses over the $N$ throughout the study for this trait agrees with Galal (2000) that there exists superiority of naked-neck and frizzled genes over normal-feathered chickens in BWT, breast girth and tibia length. 


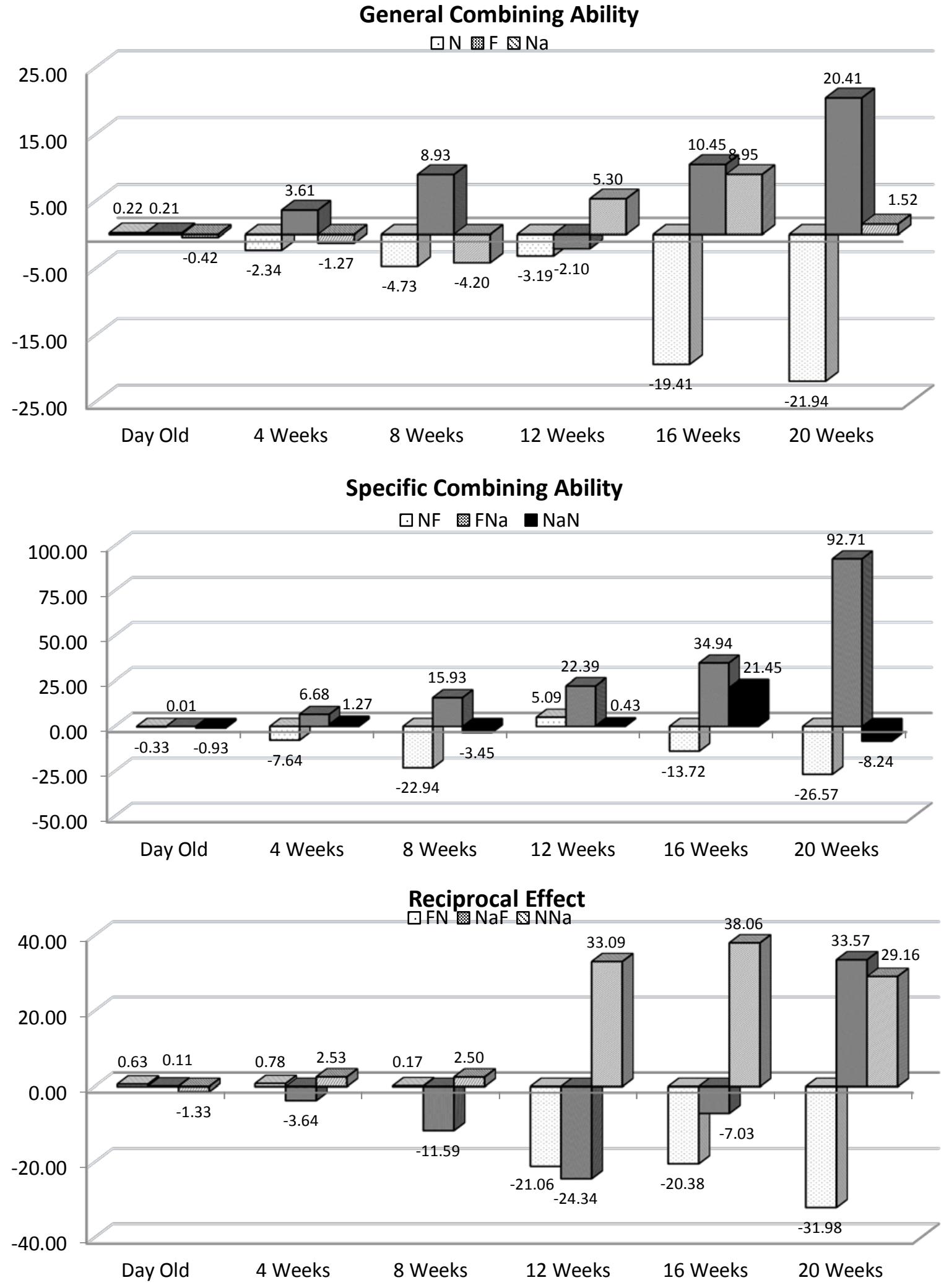

Figure 2 Estimates of general combining ability, specific combining ability and reciprocal effects for bodyweight at various ages.

The range of values $(-9.44 \%$ to $13.48 \%)$ obtained for heterosis in BWT is similar to the findings of Iraqi et al. (2011) who reported a range of $-5.24 \%$ to $9.05 \%$ when crossing occurred between Matrouh and 
Inshas chicken breeds, although results obtained in the present study yielded higher heterotic percentages than those reported by the authors. Positive heterosis is an indication that the crossbred exceeded the range of variation in BWT exhibited by its parents, while negative heterosis indicates that the crossbred fell below the range of parental variation. Reports of Wilham \& Pollak (1985) indicated that the magnitude of heterosis is inversely related to the degree of genetic resemblance between parental populations and is expected to be proportional to the degree of heterozygosity of the crosses (Sheridan, 1981). Thus, heterosis is a result of non-additive genetic effects and may be viewed as overall fitness, as well as an expression of a specific trait. According to Saadey et al. (2008), the presence of positive and high heterotic estimates at most ages may be an encouraging factor for breeders to use such crosses for the trait under consideration. This therefore, indicates that a cross between $\mathrm{F}$ males and $\mathrm{Na}$ females may be most suitable for BWT improvement in Nigeria since FNa had positive and high heterotic estimates for most ages.

The importance of additive genes in expression of BWT was observed by the significant GCA effect observed at 4th week of age which is indicative of the importance of additive genes for the expression of BWT trait (Afifi et al., 2002). The superior performance of the frizzle birds suggest that it has the upmost preponderance of genes which impact additive gene effect on BWT. Thus, the frizzle gene could lead to an increase in BWT because of the higher GCA values. Furthermore, Na showed positive GCA from week 12 to 20. Observed positive estimates for $\mathrm{F}$ and $\mathrm{Na}$ for most of the periods compared with $\mathrm{N}$, which was negative for all periods except at hatch, were partly consistent with previous reports (Ndeyebo, 2011) that the $\mathrm{Na}$ showed positive GCA estimates and indicated that the F and Na possess higher gene variation for BWT than the $\mathrm{N}$ chicken (Adebambo et al., 2010).

The estimates obtained for SCA were significant at the 16th and 20th weeks of age, which is an indication of non-additive gene action (Kabir et al., 2012). Thus, such traits could be improved by utilising non-additive gene effects such as dominance and epistatic/maternal effects and improved management practises. Furthermore, the positive SCA values for only FNa combinations throughout the periods may indicate the suitability of these two genotypes in combination for genetic improvement and gain.

The significant estimates obtained for reciprocal effect at hatch and at the 12th week of age imply that there was variation owing to sex-linked genes and maternal effect. The superior performance of NNa may be as a result of maternal effect of $\mathrm{Na}$. This result was consistent with the positive estimates obtained between Venda (normal-feathered South Africa indigenous chicken) and naked-necks (Ndeyebo, 2011). However, Cook et al. (1972) suggested that differences among male progeny of reciprocal crosses may be attributable to maternal effects and not to sex-linkage, because the homogametic males in reciprocal crosses have comparable sex chromosomes. Hence, Cook et al. (1972) stated that reciprocals test the possibility that sexlinkage is operative when significant differences are found among female progeny because each female receives its sex chromosome from its sire. The magnitude of sex linkage effects is expected to be influenced by the breeds implicated in the crossbreeding scheme, which confirms the importance of the choice breed of sire and the breed of dam in planning crossing programmes (Sabri et al., 2000).

\section{Conclusions}

The diallel analysis of three genotypes of Nigerian indigenous chickens showed that BWT was affected by genetic group. The FNa group had superior BWT compared with other genetic groups at most ages. Furthermore, the FNa gave the best estimates for heterosis and SCA, while F and NNa gave the best estimates for GCA and RE, respectively. Therefore, the use of the $\mathrm{F}$ as sire and the $\mathrm{Na}$ as dam provided the most suitable combination for the best improved BWT with a high BWT at 20 weeks old. The use of Na as dam was also most suitable since sex-linked/maternal effect was significant. In view of the estimates for GCA, SCA and RE in this study, the combination of the frizzling and naked genes as sires and dams, respectively, is highly recommended to bring about genetic improvement for BWT.

\section{References}

Adebambo, O.A., 2005. Indigenous poultry breeds genetic improvement for meat and eggs. Proc. 1st Int. Poult. Summit, Feb. 20-25, Ota, Ogun State, Nigeria. pp. 1-8.

Adebambo, A.O., Adeleke, M.A., Whetto, M., Peters, S.O., Ikeobi, C.O.N., Ozoje, M.O. Oduguwa, O.O. \& Adebambo, O.A., 2010. Combining abilities of carcass traits among pure and crossbred meat type chicken. Int. J. Poult. Sci. 9, 777-783.

Adebambo, A.O., Ikeobi, C.O.N., Ozoje, M.O., Oduguwa, O.O. \& Adebambo, O.A., 2011. Combining abilities of growth traits among pure and crossbred meat type chickens. Arch. Zootec. 60, 953-963. 
Afifi, E.A., Iraqi, M.M., El-Labban, A.M. \& Afram, M., 2002. Evaluation of heterosis and combining abilities for body weight traits in chickens. Ann. Agric. Sci. 40, 857-870.

Ajayi, F.O., 2010. Nigerian indigenous chicken: A valuable genetic resource for meat and egg production. Asian J. Poult. Sci. 4, 164-172.

Akpa, G.N., Ambali, A.L. \& Suleiman, I.O., 2013. Relationships between semen cation concentrations, semen characteristics, testicular measurements and body conformation traits in Red Sokoto goat. Nature and Science 11, 94-99.

Cook, W.T., Siegel, P.B. \& Hinkelmann, K., 1972. Genetic analyses of male mating behaviour in chickens. II. Crosses among selected and control lines. Behav. Genet. 2, 289-300.

Egahi, J.O., Dim, N.I. \& Momoh, D.M., 2013. Crossbreeding and reciprocal effect on egg weight, hatch weight and growth pattern and the interrelationships between these traits in three genetic groups of native chickens of Nigeria. Asian J. Biol. Sci. 6, 187-191.

Fairfull, R.W., 1990. Heterosis. In: Poultry Breeding and Genetics. Ed: Crawford, R.D., Elsevier, Amsterdam, The Netherlands.

FAOSTAT, 2011. Food and Agricultural Organization of the United Nations. http://faostat.fao.org/default.aspx. Accessed: July 19, 2011.

Fayeye, T.R., Ayorinde, K.L. Ojo, V. \& Adesina, O.M., 2006. Frequency and influence of some major genes on body weight and body size parameters of Nigerian indigenous chickens. Livest. Res. Rural Dev. 18, 23-26. http://www.Irrd.org//rrd18/3/faye18037.htm

Galal, A., 2000. Pleiotropic effects of naked neck, frizzled and double segregation genes on some phenotypic and genetic parameters of chickens under hot environmental conditions. Egyptian Poult. Sci. 20, 945-960.

Garces, A., Casey, N.H. \& Horst, P., 2001. Productive performance of naked neck, frizzle and dwarf laying hens under various natural climates and two nutritional treatments. S. Afr. J. Anim. Sci. 31, 174-180.

Gardner, C.O. \& Eberhardt, S.A., 1966. Analysis and interpretation of the variety cross and related populations. Biometrics 2, 439-452.

Griffing, B., 1956. Concept of general and specific combining ability in relation to diallel crossing systems. Aust. J. Biol. Sci. 9, 463-493.

Harvey, W.R., 1966. Least Squares Analysis of Data with Unequal Subclass Numbers. US Dept. Agric., Agric. Res. Service. 20, 8.

Hayman, B.I., 1954. The analysis of variance of diallel tables. Biometrics 10, 235-244.

Ikeobi, C.O.N., Ebozoje, M.O., Adebambo, O.A. \& Oshinowo, O.A., 1996. Genetic differences in the performance of Nigerian indigenous chickens. Nigerian J. Genet. 11, 55-60.

Iraqi, M.M., Hanafi, M.S., El-Moghazy, G.M., El-Kotait, A.H. \& Abdel, A'al.M.H., 2011. Estimation of crossbreeding effects for growth and immunological traits in a crossbreeding experiment involving two indigenous strains of chickens. Livest. Res. Rural Dev. 23. Retrieved: June 22, 2011, from http://www.Irrd.org/lrrd23/4/iraq23082.htm

Kabir, M., Akpa, G.N., Nwagu, B.I. \& Adeyinka, I.A., 2012. Litter traits in a diallel crossing of three rabbit breeds in northern guinea savannah zone of Nigeria. Proc. 10th World Rabbit Congress - September 3 - 6, Sharm El- Sheikh, Egypt. pp. 67-74.

Khalil, M.K., Al-Homidan, A.H. \& Hermes, I.A., 2004. Crossbreeding components in age at first egg and egg production for crossing Saudi chickens with White Leghorn. Res. Rural Dev. Online Journal: http://www.cipav.org.co/1rrd15/khaliltmp.htm.

Kitalyi, A.J., 1999. Family poultry management systems in Africa. In: The Scope and Effect of Family Poultry Research and Development. Ed: Guèye, E.F., First INFPD/FAO Electronic Conference on Family Poultry http://www.fao.org/WAICENT/FAOINFO/AGRICULT/AGA/AGAP//ps/fampo/leadpap3.htm

Mahrous, M.Y., 2008. Effect of interaction between some major and marker genes on immune response and productive performance of chickens. PhD thesis, Faculty of Agriculture, Ain Shams University, Egypt.

Minga, U., Msoffe, P.L. \& Gwakisa, P.S., 2004. Biodiversity (variation) in disease resistance in pathogens within rural chicken. Proc. Wrld Poult. Congress, June 8-21, Istanbul, Turkey.

Msoffe, P.L., Minga, U.M., Olsen, J.E., Yongolo, M.G., Juul-Madsen, H.R., Gwakisa, P.S. \& Mtambo, M.M., 2001. Phenotypes including immune-competence in scavenging indigenous chicken ecotypes in Tanzania. Trop. Anim. Health Prod. 33, 341-354.

Ndeyebo, A.S., 2011. Heterosis and combining ability for body weight in a diallel cross of three chicken genotypes. M.Sc. thesis, Faculty of Science and Agriculture, University of Limpopo, South Africa. pp. 19-25.

Ndofor-Foleng, H.M., Ngongeh, L.A., Uberu, C.P.N. \& Nwosu, C.C., 2010. Evaluation of the performance of two local chicken and the main cross ecotypes reared in Nsukka, Enugu State, Nigeria. Int. J. Sci. Nature 1 (2), 179-182. 
Nwachukwu, E.N., Ibe, S.N., Ejekwu, K. \& Oke, U.K., 2006. Evaluation of growth parameters of main and reciprocal crossbred normal, naked neck and frizzle chickens in a humid tropical environment. J. Anim. Vet. Adv. 5, 542-546.

Oke, U.K., 2011. Influence of some major genes on growth traits of indigenous pullets in humid tropical environment. Agric. Biol. J. North America, doi: 10.5251/abjna.2011.2.4.570.576.

Peters, S.O., 2000. Genetic variation in the reproductive performance of indigenous chicken and growth of pure and half bred progeny. M. Agric thesis submitted to department of Animal Breeding and Genetics, University of Agriculture, Abeokuta, Nigeria.

Petrus, N.P., 2011. Characterization and production performance of indigenous chickens. In: Northern Namibia Regions. PhD thesis. Department of Animal Science of the University of Namibia. pp. 242. http://www.isis.unam.na/theses/petrus2011.pdf

R Core Team, 2013. R: A language and Environment for Statistical Computing. R Foundation for Statistical Computing, Vienna, Austria. URL http://www.R-project.org/

Saadey, S., Mekky, A., Galal, H.I., Zaky, I. \& Zein El-Dein, A., 2008. Diallel crossing analysis for body weight and egg production traits of two native Egyptian and two Exotic chicken breeds. Int. J. Poult. Sci. 7, 64-71.

Sabri, H.M., Khattab, M.S. \& Abdel-Ghany, A.M., 2000. Genetic analysis for body weight traits of a diallel crossing involving Rhode Island Red, White Leghorn, Fayoumi and Dandarawi chickens. Ann. Agric. Sci. 38, 1869-1883.

SAS, 2002. Statistical Analysis System, Computer Software, Version 9: Statistics SAS Institute Inc. Cary, N.C. 27513, USA.

Sheridan, A.K., 1981. Crossbreeding and heterosis. Anim. Breed. Abstr. 49, 131-144.

Singh, R.P. \& Kumar, J., 1994. Biometrical Methods in Poultry Breeding. Kalyani Publishers, New Delhi, India. pp. 240.

Willham, R.L. \& Pollak, E., 1985. Theory of heterosis. J. Dairy Sci. 68, 2411-2417.

Yunus, R. \& Cahaner, A., 1999. The effects of the naked neck ( $\mathrm{Na}$ ) and frizzle genes and growth and meat yield of broilers and their interaction with ambient temperatures and potential growth rate. Poult. Sci. 78, 1347-1352. 